Indexed by

\title{
Scopus REDUCE THE FIRE RISK IN THE OIL AND GAS INDUSTRY: PERFORMANCE, FEATURES AND IMPLEMENTATION
}

Crossref

KOBSON

I8 Google

\author{
Aleksei V. Ivanov \\ Saint-Petersburg University \\ of the State Fire Service of \\ EMERCOM of Russia, \\ Department of fire safety \\ of technological processes \\ and production, \\ Saint-Petersburg, Russia \\ Igor L. Skripnick \\ Saint-Petersburg University \\ of the State Fire Service of \\ EMERCOM of Russia, \\ Department of fire safety \\ of technological processes \\ and production, \\ Saint-Petersburg, Russia
}

\author{
Farid A. Dali \\ Saint-Petersburg University \\ of the State Fire Service of \\ EMERCOM of Russia, \\ Department of fire safety \\ of technological processes \\ and production, \\ Saint-Petersburg, Russia
}

\section{Marina A. Simonova \\ Peter the Great St. Petersburg Polytechnic University, The Higher school of technosphere safety of Construction institute, Saint-Petersburg, Russia}

\author{
Grigoriy K. Ivakhnyuk \\ Saint-Petersburg State \\ Institute of Technology, \\ Department of Engineering \\ Protection of Environment, \\ Saint-Petersburg, Russia
}

Key words: liquid hydrocarbons, extinguishing, variable frequency-modulated potential, fire risk, carbon nanotubes

Cite article:

Aleksei, V. I., Farid, A. D., Grigoriy, K. I., Igor, L. S., Marina, A. S., \& Denis, V. S. [2021]. Nanostructures management technology to reduce the fire risk in the oil and gas industry: performance, features and implementation. Journal of Applied Engineering Science, 19(1) 84 - 91. DOI:10.5937/ jaes $0-26622$

Online aceess of full paper is available at: www.engineeringscience.rs/browse-issues 


\title{
NANOSTRUCTURES MANAGEMENT TECHNOLOGY TO REDUCE THE FIRE RISK IN THE OIL AND GAS INDUSTRY: PERFORMANCE, FEATURES AND IMPLEMENTATION
}

\author{
Aleksei V. Ivanov ${ }^{1 *}$, Farid A. Dali', Grigoriy K. Ivakhnyuk², Igor L. Skripnick', Marina A. Simonova ${ }^{3}$, \\ Denis V. Shikhalev ${ }^{4}$ \\ ${ }^{1}$ Saint-Petersburg University of the State Fire Service of EMERCOM of Russia, Department of fire \\ safety of technological processes and production, Saint-Petersburg, Russia \\ ${ }^{2}$ Saint-Petersburg State Institute of Technology, Department of Engineering Protection of Environment, \\ Saint-Petersburg, Russia \\ ${ }^{3}$ Peter the Great St. Petersburg Polytechnic University, The Higher school of technosphere safety of \\ Construction institute, Saint-Petersburg, Russia \\ ${ }^{4}$ State Fire Academy of EMERCOM of Russia, Department of information support of the population and \\ technologies fire safety, Moscow, Russia
}

Oil and gas enterprises are characterized by an increased fire risk. There is high probability of occurrence and spread of large fires when oil production and processing, transportation and storage of oil products occurs. There is high probability of large fires during the oil production, oil processing and during the transportation and storage of petroleum products. New materials created using nanotechnology principles are needed to improve the efficiency of fire prevention and extinguishing systems. The technology for controlling the properties and performance characteristics of nanofluids based on liquid hydrocarbons and water is based on the methods of functionalization and interaction of clusters of the base liquid and multilayer carbon nanotubes, methods for stabilizing nanofluids, for changing the thermophysical, rheo-logical and electrostatic properties of substances and materials on their basis. The proposed technology makes it possible to create nanomaterials based on various scenarios for the development of emergency situations and to apply them to reduce fire risk at oil and gas facilities.

Key words: liquid hydrocarbons, extinguishing, variable frequency-modulated potential, fire risk, carbon nanotubes

\section{INTRODUCTION}

The development of the oil and gas complex is related to the unstable demand of the world market, the growth of capital investments in the industry, the low level of profitability caused by the state's require-ments for labor protection and environmental safety, the need to process raw materials with worsening commodity indicators [1]. The development trends of the oil and gas industry are an increase in the share of "heavy" oil in total production, an increase in the number of drilling rigs from large depths, an expansion of the geography of production towards the northern territories with difficult climatic conditions [2], a shift in priorities towards oil refining [3].

The methodology of fire risk assessment in oil and gas refineries and related industries includes the de-scription of process control tools and emergency systems, identification of hazards, scenarios and fre-quency of incidents, simulation of consequences and assessment of the impact of potential accidents and fires. Common emergencies and complications in the extraction, transportation, processing of petroleum and petroleum products are strait fires, flares, hydrocarbon flames, the formation of a fireball, the combustion of a vapor cloud under pressure. The most dangerous of them occur on land tanks with the subsequent ignition of oil or oil products with fire and complete destruction. Partial destruction and leaks from process equipment and pipelines are most likely [4].

When implementing measures to reduce fire risk, restrictions arise due to the "growth limits" of modern fire safety technologies, which are associated with a number of factors:

- the impossibility of changing physical properties (evaporation rate, surface tension, viscosity, static electrification, etc.) when handling substances and materials without the use of technical solutions that make significant changes in the process parameters;

- problems of ensuring the required values of thermal conductivity, adhesive strength, thermal stability of thermal protection means and intumescent fire retardant compositions for metal structures at tem-perature conditions corresponding to the conditions of flare hydrocarbon combustion;

- limited possibility to use materials with high fire-extinguishing efficiency and thermal protection under standard fire extinguishing systems.

- The solution to this problem of increasing the efficiency of technical solutions for ensuring fire safety in modern oil and gas enterprises is possible when developing methods for modifying and producing nanomaterial with desired physicochemical proper- 
ties. Successful implementation of such technologies is possible when solving problems:

- development of methods for "reverse" changes in the properties of substances at the stage of application of technologies characterized by the highest probability of an emergency or fire;

- provide relatively low material costs for the implementation of the so-called "smart materials" in exist-ing production and maintenance of fire safety systems;

- exclude the negative impact of the proposed technologies on the person, the environment, applying to the production of substances, materials and products.

One of the most promising ways to solve this problem is the development of nanotechnologies for the formation and use of supra molecular self-organizing carbon meso structures with predictable characteristics, in chemical reactions and at the interface, which have already found application in technologies for creating nanofluids, structural materials and composites. These characteristics depend largely on thermal physics electrostatic properties of carbon nanomaterial, as well as their linear and volumetric characteristics on nanostructures [5].

\section{MATERIALS AND METHODS}

The objects of study were selected multilayer carbon nanotubes (MWCNT), which are extended cylindrical and branching nanostructures $(\mathrm{d}=30 \mathrm{~nm}, \mathrm{I}=1 \ldots 5 \mu \mathrm{m})$. MWCNT were obtained by catalytic pyrolysis using the CVDomna. MWCNTs underwent reagent functionaliza- tion for purification from synthesis by-products in order to improve their performance characteristics [6].

Distilled water, mixtures (NEFRAS C3-80 / 120 "BR-1" gasoline, TS-1 kerosene) liquid hydrocarbons and individual organic substances (o-xylene, ethanol) were used as base fluids. The main properties of the studied base fluids under normal conditions are presented in Table 1.

For nanofluids based on water, the red-cross-linked acrylic acid polymer (PAA) "Carbopol ETD 2020" was used as a surfactant to stabilize water clusters and carbon nanostructures. The effect of variable frequen-cy-modulated potential (VFMP) with parameters $56 \ldots 220 \mathrm{~V}(50 \mathrm{~Hz})$ [7] for 30 min was applied when dis-persing MWCNT and adding surfactant.

The following methods were used in the work: Raman spectroscopy [8]; measurements of the dielectric constant of nanofluids by the method of a flat capacitor; electrical resistivity measurements [9]; measurements of the surface tension coefficient by the method of detachment of drops [10]; atomic force microscopy [11]; studies of the thermo physical properties of liquids in a laboratory setup for studying the processes of surface and bulk boiling of liquids [12]; studies of the processes of flow and evaporation of modified hydrocarbon liquids [7]; studies of electrification processes when handling modified hydrocarbon liquids during their pumping, homogenization and spraying [13]; studies of the extinguishing properties of modified formulations based on water and hydrogels [14]; studies of the operational characteristics of nanomodified flame retardant intumescent compositions in the conditions of the flare combustion of hydrocarbons (jetfire) [15].

Table 1: The properties of base fluids

\begin{tabular}{|c|c|c|c|c|c|c|c|c|}
\hline № & Base fluid & $\begin{array}{c}\text { Flash } \\
\text { point, }{ }^{\circ} \mathrm{C}\end{array}$ & $\begin{array}{c}\text { Molecular } \\
\text { mass, } \\
\mathrm{g} / \mathrm{mol}\end{array}$ & $\begin{array}{c}\text { Density at } \\
20^{\circ} \mathrm{C}, \rho, \\
\mathrm{g} / \mathrm{cm}^{3}\end{array}$ & $\begin{array}{c}\text { Surface } \\
\text { tension, } \\
\sigma \cdot 10^{-3} \mathrm{H} / \mathrm{M}\end{array}$ & $\begin{array}{c}\text { The } \\
\text { dielectric } \\
\text { constant, } \varepsilon\end{array}$ & $\begin{array}{c}\text { Specific } \\
\text { volumetric } \\
\text { electrical } \\
\text { resistance, } \\
\rho_{\mathrm{v}}, \text { OM} \cdot \mathrm{M}\end{array}$ & $\begin{array}{c}\text { Thermal } \\
\text { conductivity, } \\
\lambda \cdot 10^{3} \mathrm{~W} /(\mathrm{m} \\
\cdot \mathrm{K})\end{array}$ \\
\hline 1. & $\begin{array}{c}\text { Distilled } \\
\text { water } \\
(\mathrm{DW})\end{array}$ & - & 18 & 0,9998 & 72,8 & 81 & $10^{3} \ldots 10^{4}$ & 612 \\
\hline 2. & $\begin{array}{c}\text { Nefras } \\
\text { C3-80/120 } \\
(\text { BR-1) }\end{array}$ & -9 & 98 & 0,73 & 21,1 & 2,3 & $10^{10} \ldots 10^{12}$ & 139 \\
\hline 3. & $\begin{array}{c}\text { Kerosene } \\
(\mathrm{TS}-1)\end{array}$ & 28 & 151,2 & 0,78 & 24,3 & 1,8 & $(1 \ldots 6) \cdot 10^{11}$ & 126 \\
\hline 4. & $\begin{array}{c}\text { O-xylene } \\
5 .\end{array}$ & 46 & 106,17 & 0,8621 & 30,03 & 2,6 & $3,3 \cdot 10^{12} \ldots$ & 131 \\
\hline Ethanol & 13 & 46,069 & 0,7893 & 22,1 & 24,3 & $7,7 \cdot 10^{13}$ & 167 \\
\hline
\end{tabular}




\section{THE RESULTS OF EXPERIMENTAL STUDIES}

In the study of MWCNT using Raman spectroscopy, data were obtained on the presence of large amounts of amorphous carbon and impurities in non-functionalized MWCNT, as evidenced by the ab-sence of pronounced D-lines $(\sim 1400 \mathrm{~cm})$ and G-lines $\left(\sim 1600 \mathrm{~cm}^{-1}\right)$ in the spectrum of the substance. After functionalization, the carbon nanomaterial contained a structured carbon material and had a well-defined G-line in the region of 1600 $\mathrm{cm}^{-1}$ (Figure 1).

The results suggest that dispersion of non-functionalized MWCNT in water reduces surface tension by $10-22 \%$ compared with the base fluid, which is associated with the presence of by-products of the syn-thesis of nanoparticles acting as surfactants.

The use of functionalized MWCNT increases the surface tension in comparison with the base fluid by $20-27 \%$. Addition of PAA "Carbopol ETD 2020" at a concentration of 0.15 wt. \% significantly (by $48-66 \%$ ) reduces the magnitude of the surface tension of nanofluid in comparison with distilled water. The disper-sion of functionalized MWCNT into nanofluid based on "Carbopol ETD 2020" allows increasing the sur-face tension of liquid based on distilled water from PAA "Carbopol ETD 2020" by 10-15\%. For nanofluids based on liquid hydrocarbons, the addition of functionalized MWCNTs allows an increase in the surface tension coefficient by $8-58 \%$ compared to base fluids.

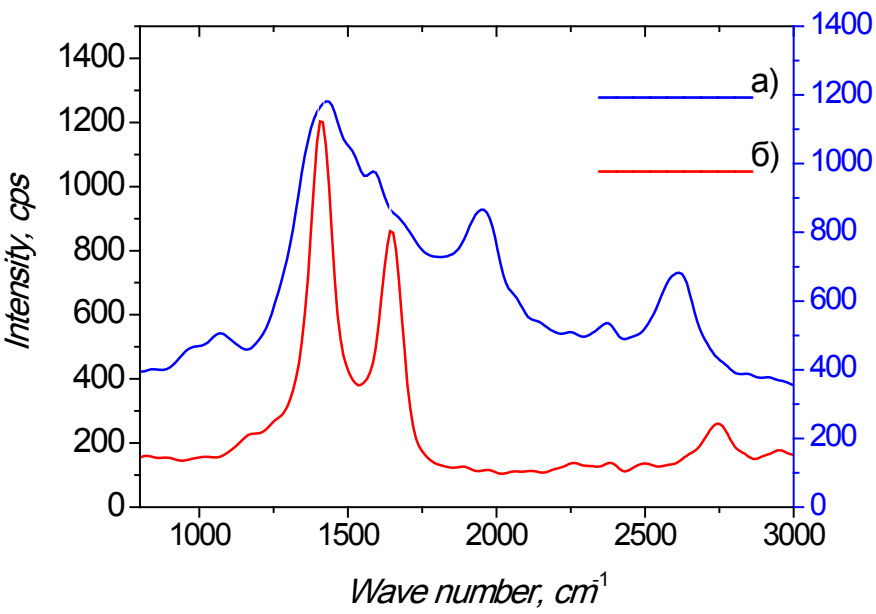

Figure 1: Raman spectrum MWCNT: non-functionalized (a); functionalized (b)

Data on the relative change in the dielectric constant of modified liquids are presented in Fig. 3. For all samples of nanofluids, the dielectric constant decreases by $10-80 \%$ compared to the base fluid. An in-crease in the change in dielectric constant values occurs with an increase in the concentration of carbon nanoparticles. This effect is explained by a decrease in the actual $\varepsilon$ 'and imaginary $\varepsilon$ ' 'parts of the complex permittivity due to the restructuring of the nanoparticles in substances $[16,17]$.

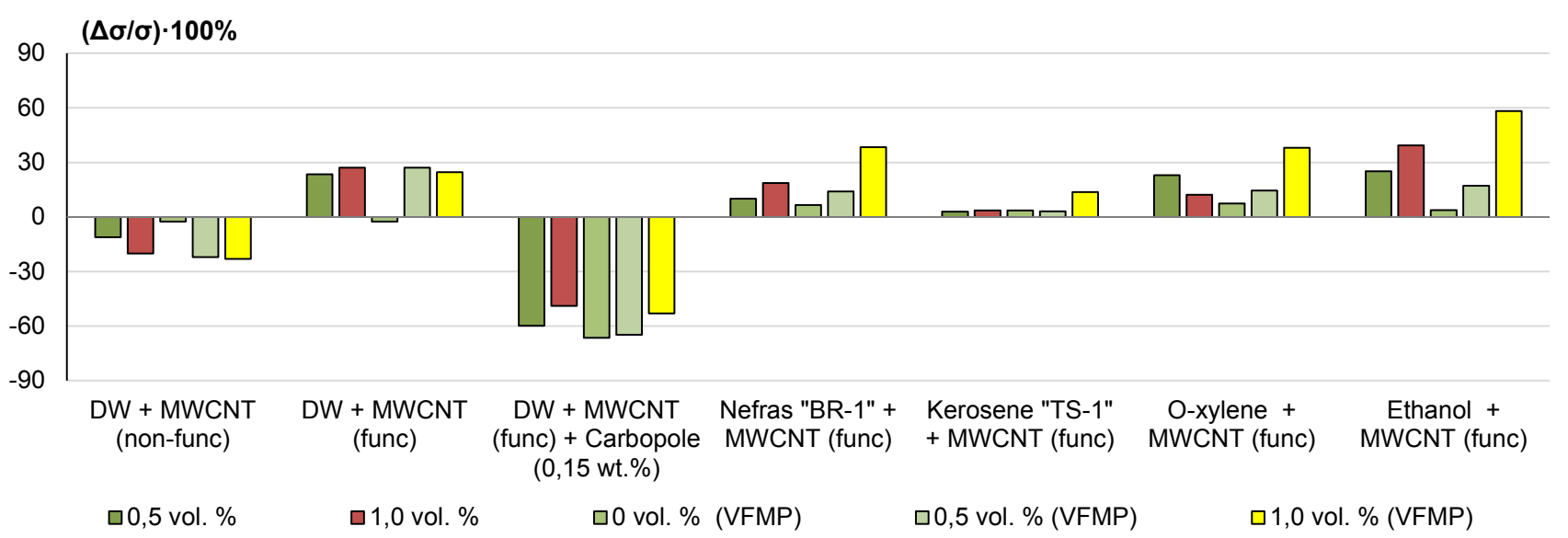

Figure 2: Relative change in the surface tension of modified fluids

\section{$(\Delta \varepsilon / \varepsilon) \cdot 100 \%$}



Figure 3: Relative change in the dielectric constant of modified fluids 
$\left(\Delta \rho_{v} / \rho\right) \cdot 100 \%$

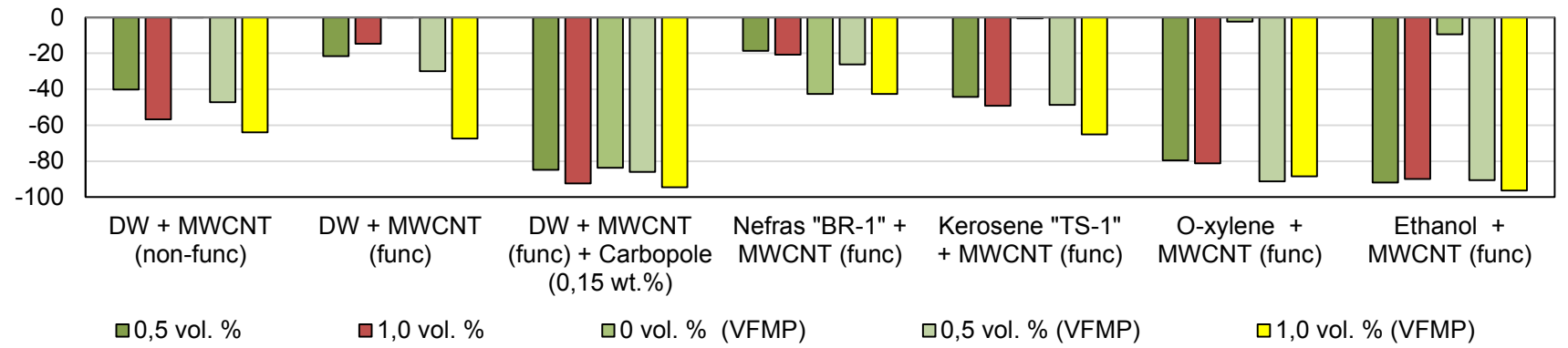

Figure 4: Relative change in the specific volume electrical resistance of modified nanofluids

Data on the relative change in the specific volume electrical resistance of modified liquids is presented in Fig. 4. The specific volume electrical resistance of nanofluids is reduced with the introduction of non-functionalized and functionalized nanoparticles to $96 \%$. In general, an increase in the concentration of nanoparticles contributes to a decrease in the specific volume electrical resistance of nanofluids.

When studying the effect of dispersed MWCNT on the properties of nanofluids, it was noted that for individual samples of nanofluids with an increase in the concentration of MWCNT nanoparticles to $1.0 \mathrm{vol}$. \% there is no significant change in the values of surface tension, dielectric constant and specific volume electrical resis- tance, which is associated with exceeding the percolation threshold for nanofluids, as well as intensive agglomeration of nanoparticles [18]. In the conditions of electrophysical exposure, there is an additional change (from $3 \%$ to $20 \%$ ) of the studied values. The result obtained is associated with a decrease in the aggregation of MWCNT in nanofluid and a slower decrease in the working concentration of nanoparticles with macromolecules of basic liquids [19].

The results of the study of nanoparticle traces in nanofluids based on water, o-xylene and ethanol at an MWCNT concentration of 1.0 vol. \% Using the AFM method (AFM) are presented in Fig. 5.

$D W$

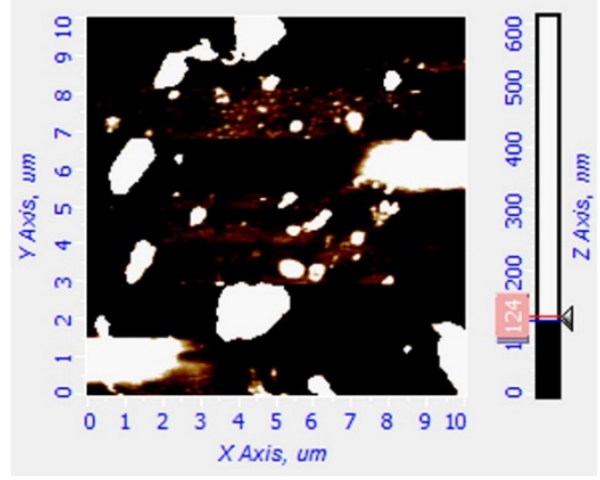

(a)

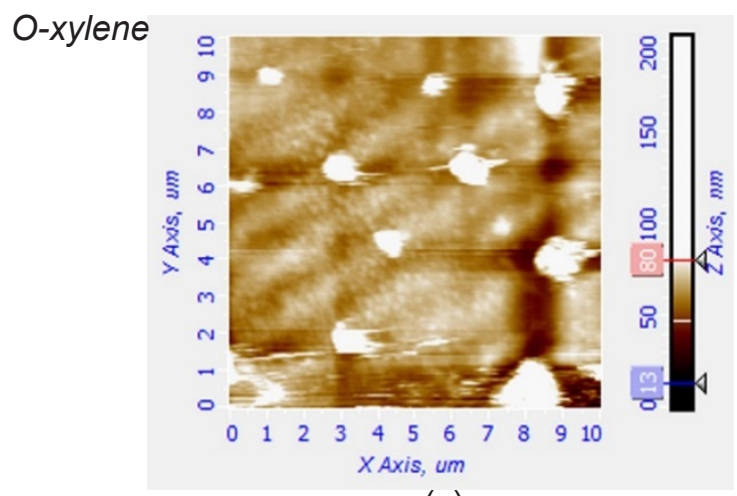

(c)

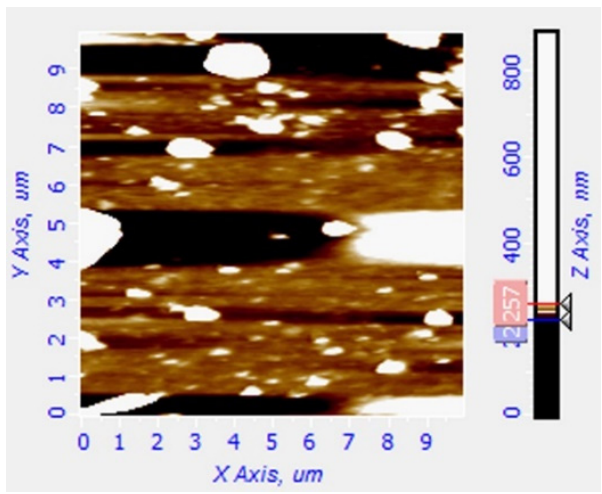

(b)

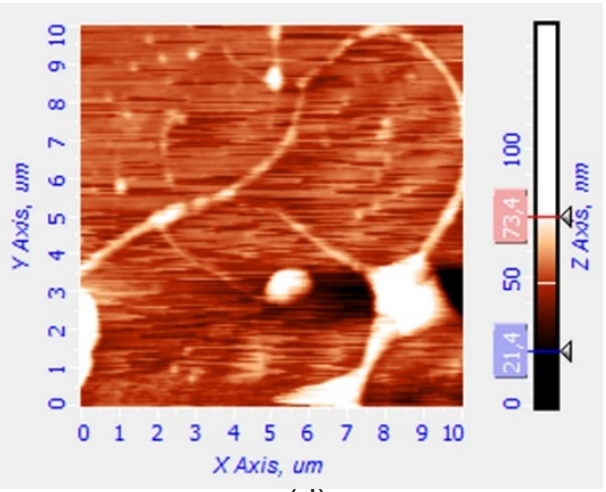

(d) 


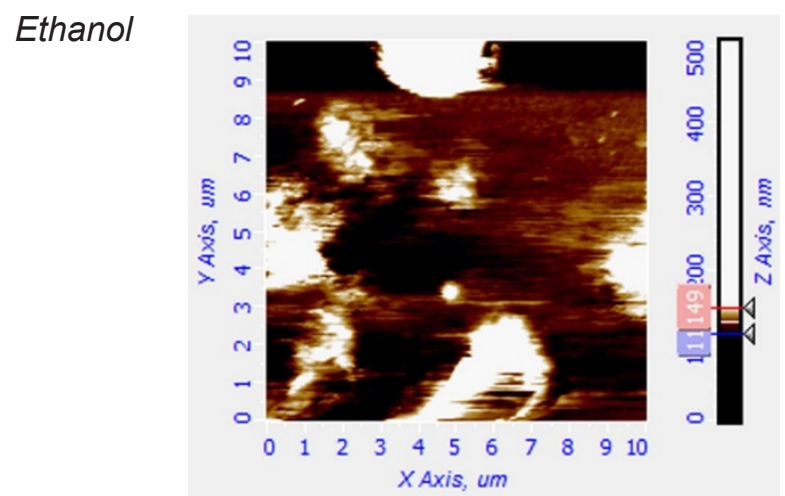

(e)

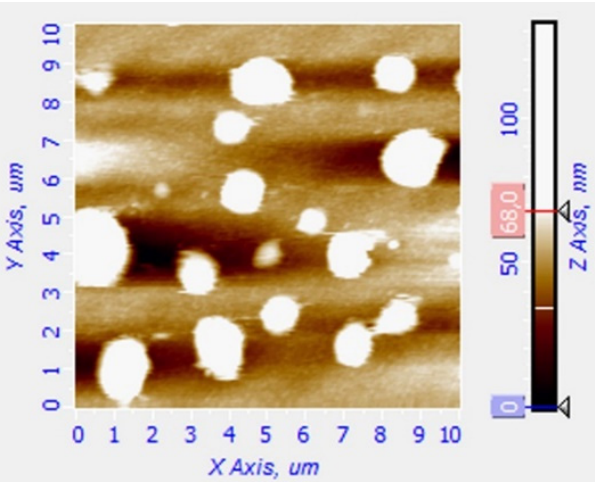

(f)

Figure 5: AFM scans agglomerations MWCNT at a concentration of $1.0 \mathrm{vol} . \%$ in the nanofluid: without electrophysical influence $(a, c, e)$, under the influence of VFMP $(b, d, f)$

In the course of the study, it was revealed that under electro physical effects, self-organization of MWCNT nanoparticles in nanofluids, a reduction in the size of aggregating particles and the distance between individual particles occurs. A decrease in the aggregation of nanoparticles and the stabilization of nanofluids occurs due to the adsorption of ions on the surface of the material. Adsorption creates a double electric layer, in consequence of which repulsion appears between the nanoclusters. The application of an alternating electric field to a solution or a dispersed system leads to the forced motion of charged particles, thereby changing the value of the zeta potential, which leads to a change in the stability parameters of liquid systems [20]. Metallic nanoparticles (Ni) are present in the MWCNT obtained by the method of catalytic pyrolysis, which causes the appearance of "micro wires" with simultaneous orientation along the lines of force of the electric field [21].

Data on changes in the properties of substances and materials obtained using modified liquids are pre-sented in Table 2. The results indicate the possibility of using nanotechnology solutions to improve the effectiveness of measures in response to accidents and extinguishing fires at oil and gas industry facili-ties.

Table 2: Data on the change in the properties of substances and materials obtained using modified nanofluids

\begin{tabular}{|c|c|c|}
\hline Nano materials & Characteristics versus unmodified substances and materials & Source \\
\hline $\begin{array}{l}\text { Gasoline NEFRAS "BR-1" with } \\
\text { functionalized MWCNT } \\
(0.5 \ldots 1.0 \text { vol. } \%)\end{array}$ & $\begin{array}{l}\text { Increasing the surface tension by } 6 \ldots 25 \% \text {, reducing the flow } \\
\text { rate by } 12 \ldots 15 \% \text {, reducing the evaporation rate from the open } \\
\text { surface by } 30 \% \text {. Decrease in electric field intensity during } \\
\text { ho-mogenization by } 5 \text { times. }\end{array}$ & [13] \\
\hline $\begin{array}{c}\text { Kerosene "TS-1" with func-tionalized } \\
\text { MWCNT }(0.5 \ldots 1.0 \text { vol. } \%)\end{array}$ & $\begin{array}{l}\text { An increase in the surface tension by } 6 \% \text {, a decrease in the } \\
\text { flow rate by } 10 \ldots 24 \% \text {, a decrease in the evaporation rate from } \\
\text { the open surface by } 38 \% \text {. Decrease in electric field strength } \\
\text { during homogenization by } 8 \text { times. Increase the flash point of } \\
\text { kerosene from } 29 \text { to } 37^{\circ} \mathrm{C} \text {. }\end{array}$ & {$[13,22]$} \\
\hline $\begin{array}{l}\text { O-xylene with non-functionalized } \\
\text { MWCNT (0.5 ... } 1.0 \text { vol.\%) }\end{array}$ & $\begin{array}{l}\text { Increase in surface tension by } 12-38 \% \text {. Decrease in electrifi- } \\
\text { ca-tion during pneumatic spraying of flame retardant intumes- } \\
\text { cent compositions based on o-xylene to } 2.7 \text { times. Increasing } \\
\text { the thermal stability of flame retardant intumescent composi- } \\
\text { tions in the conditions of the flare combustion of hydrocarbons. }\end{array}$ & [23] \\
\hline $\begin{array}{l}\text { Ethanol with functionalized MWCNT } \\
\qquad(0.5 \ldots 1.0 \text { vol. } \%)\end{array}$ & $\begin{array}{l}\text { Reducing the evaporation rate to } 30 \% \text {. Decrease in electriza- } \\
\text { tion at homogenization up to } 8 \text { times. Increase flash point from } \\
13 \text { to } 24^{\circ} \mathrm{C} \text {. }\end{array}$ & {$[9,23]$} \\
\hline $\begin{array}{l}\text { Hydrogels based on water with a } \\
\text { concentration of RAP "Carbopol } \\
\text { ETD 2020" } 0.1 \ldots 0.2 \text { wt. } \%\end{array}$ & $\begin{array}{l}\text { Increase heating rate to boiling point by } 85 \% \text {. Reduction in } \\
\text { sur-face tension by } 57 \% \text {. Reducing the time of extinguishing of } \\
\text { model foci of solid combustible materials by } 50 \% \text {. }\end{array}$ & {$[24,25]$} \\
\hline $\begin{array}{c}\text { Hydrogels based on water with RAP } \\
\text { "Carbopol ETD } 2020 "(0,2 \text { wt. } \%) \text { With } \\
\text { non-functionalized } \\
\text { MWCNT }(0.5 \ldots 1.0 \text { vol. } \%) \\
\end{array}$ & $\begin{array}{l}\text { Increase the heating rate to the boiling point by } 60 \% \text {. Reduction } \\
\text { in surface tension by } 52 \% \text {. Reducing the time of extinguishing } \\
\text { model foci of flammable liquids by } 4.5 \text { times. }\end{array}$ & [26] \\
\hline $\begin{array}{l}\text { Distilled water with non-functionalized } \\
\text { MWCNT }(0.5 \ldots 1.0 \text { vol. } \%)\end{array}$ & $\begin{array}{l}\text { Increase heating rate to boiling point by } 40 \% \text {. Reduction in sur- } \\
\text { face tension by } 20 \% \text {. Reducing the time of extinguishing model } \\
\text { foci of flammable liquids by } 5.5 \text { times. }\end{array}$ & [26] \\
\hline
\end{tabular}


Table 3: Properties of substances that determine the likelihood of developing emergency situations at oil and gas facilities

\begin{tabular}{|c|c|c|c|}
\hline Emergency situations & $\begin{array}{l}\text { Properties of } \\
\text { substances }\end{array}$ & $\begin{array}{c}\text { Nature of } \\
\text { management }\end{array}$ & Effect \\
\hline \multirow{4}{*}{$\begin{array}{l}\text { The formation of a com- } \\
\text { bustible medium in case of } \\
\text { emergency spills of liquid } \\
\text { hydrocarbons }\end{array}$} & Surface tension & Increase & $\begin{array}{l}\text { Reducing the flow rate of fluids through small } \\
\text { openings. Reducing the evaporation rate of } \\
\text { liquids from an open surface }\end{array}$ \\
\hline & $\begin{array}{c}\text { Thermal } \\
\text { conductivity }\end{array}$ & Increase & $\begin{array}{l}\text { Lowering the temperature of the liquid due to the } \\
\text { intensification of the heat sink }\end{array}$ \\
\hline & $\begin{array}{l}\text { Saturated steam } \\
\text { pressure }\end{array}$ & Decrease & \multirow{2}{*}{$\begin{array}{l}\text { The decrease in the intensity of the formation } \\
\text { of a combustible medium in the apparatus with } \\
\text { liquids }\end{array}$} \\
\hline & Flash point & Increase & \\
\hline \multirow{2}{*}{$\begin{array}{l}\text { Ignition of flammable liquid } \\
\text { hydrocarbons from generat- } \\
\text { ed static discharges }\end{array}$} & $\begin{array}{c}\text { The dielectric } \\
\text { constant }\end{array}$ & Decrease & $\begin{array}{l}\text { Decrease in electrification when handling liquid } \\
\text { hydrocarbons }\end{array}$ \\
\hline & $\begin{array}{c}\text { Electrical } \\
\text { conductivity }\end{array}$ & Increase & $\begin{array}{l}\text { Intensification of the electrostatic discharge } \\
\text { process }\end{array}$ \\
\hline \multirow{2}{*}{$\begin{array}{l}\text { Thermal effects in the flare } \\
\text { combustion of hydrocarbons }\end{array}$} & $\begin{array}{c}\text { Thermal } \\
\text { conductivity }\end{array}$ & Decrease & $\begin{array}{l}\text { Reducing the rate of temperature rise with the } \\
\text { contact heating mechanism }\end{array}$ \\
\hline & Thermal stability & Increase & $\begin{array}{l}\text { Increasing the time of protection of thermal pro- } \\
\text { tection elements }\end{array}$ \\
\hline \multirow{3}{*}{$\begin{array}{l}\text { Extinguishing of fires of } \\
\text { straits, torch burning of } \\
\text { hydrocarbons by fire extin- } \\
\text { guishing compositions on the } \\
\text { basis of water }\end{array}$} & $\begin{array}{c}\text { Thermal } \\
\text { conductivity }\end{array}$ & Increase & $\begin{array}{l}\text { Increasing the heating rate of fire extinguishing } \\
\text { substances to the boiling point }\end{array}$ \\
\hline & $\begin{array}{l}\text { Specific heat of } \\
\text { vaporization }\end{array}$ & Increase & $\begin{array}{l}\text { Intensification of the heat sink in the combustion } \\
\text { zone }\end{array}$ \\
\hline & Surface tension & Decrease & $\begin{array}{l}\text { The increase in the intensity of evaporation of } \\
\text { the extinguishing agent in the combustion zone }\end{array}$ \\
\hline
\end{tabular}

\section{DISCUSSION}

To implement the fire risk management system at oil and gas enterprises, it is necessary to take a set of organizational and technical measures to reduce the hazardous manifestations of ignition sources, re-duce the likelihood of leaks, limit the spreading and evaporation of flammable and combustible liquids, and protect against local liquid exit due to the destruction of process equipment. When fires and fires occur in process plants and tanks, it is necessary to use fire extinguishing and thermal protection systems, intumescent fire retardant coatings and structural thermal protection [4].

The decision-making process in managing fire risks at oil and gas facilities is based on the results of the assessment of the fire protection status of the objects of protection, the assessment of environmental parameters, the choice of technologies and methods for determining fire risks, as well as methods of their management and control. In this case, the likelihood of emergency situations and the effects of fire hazards is largely determined by the physicochemical properties of substances and materials circulating in technological processes and used to eliminate accidents and extinguishing fires. The introduction of Nano technological solutions to change the properties of the circulating substances and materials, as well as the use of fire extinguishing agents and fire protection equipment of increased efficiency allows redistributing the likelihood of emergency situations and reducing the calculated fire risk values at oil and gas enterprises (Table 3).

The process of developing technologies for the creation and use of nanomaterials to ensure fire safety at oil and gas facilities can be represented as a functional flowchart (Fig. 6):

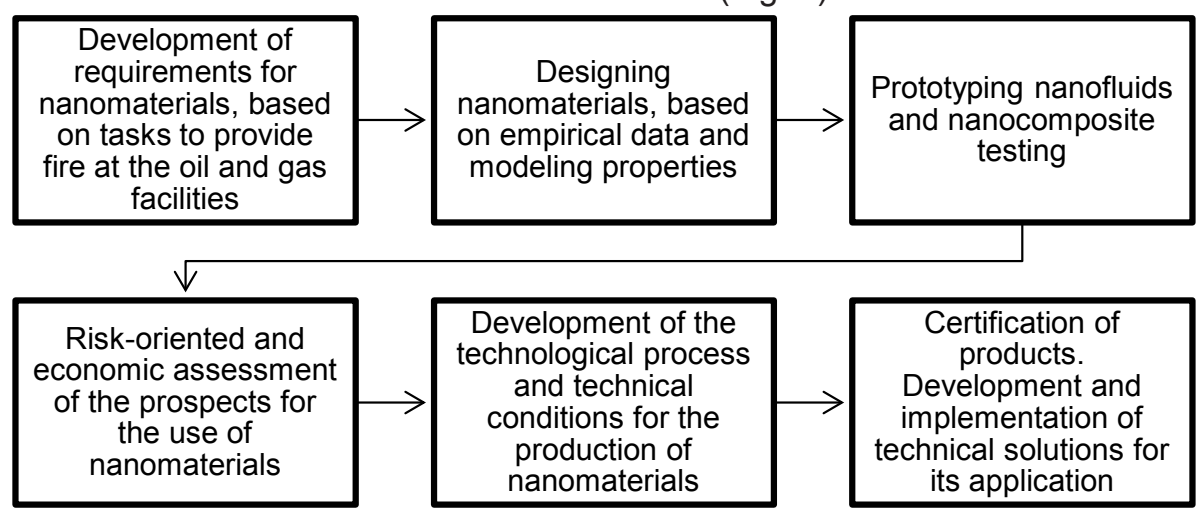

Figure 6: Functional block diagram of the development of technology for obtaining nanomaterials for solving problems of ensuring fire safety 
Development of requirements for the performance characteristics of nanomaterials and their design is carried out based on the tasks of localizing emergency spills and ensuring electrostatic intrinsic safety when handling flammable and combustible liquids, reducing the flammability of nanocomposites, and improving the adhesion characteristics of protective coatings based on them, intensifying heat exchange processes when applying fire extinguishing agents, as well as ensuring the stability of the nanostructure of the material at the stages of production, application and operation.

Prediction of the properties of nanomaterials should be based on the results of statistical processing of empirical data [27]. The main factors determining the properties of nanomaterials in the context of ensur-ing electrostatic intrinsic safety when handling liquid hydrocarbons are: dielectric constant and specific volume electrical resistance of base fluids, surface tension of nanofluids, indicators of dispersion and figure of merit of MWCNT nanoparticles, as well as the presence of factors stabilizing nanosystems (using an electro physical method influences and surfactant). To increase the effectiveness of fire extinguishing, technologies should be applied to increase thermal conductivity and reduce the surface tension of fire extinguishing compositions based on water, subject to the use of standard fire extinguishing installations and firefighting equipment.

\section{CONCLUSIONS}

The results obtained during the study lead to the following conclusions.

1. The need to develop new technologies for creating nanomaterials to ensure fire safety at oil and gas facilities is due to the "growth limits" of modern technologies for limiting and localizing emergency situations and fire extinguishing, which does not allow you to quickly manage the physical and chemical properties of the circulating substances and materials when handling liquid hydrocarbons.

2. The direction of developing new technologies to improve the efficiency of emergency and fire extin-guishing at oil and gas facilities is associated with the creation of new methods for modifying the base substance in the meso structure (in particular, water and liquid hydrocarbons) by introducing carbon clusters (nanomaterials with MWCNT) and management into it processes of stabilization and self-organization of nanostructures in liquids and composites due to external electro physical effects.

3. The proposed technology for controlling the thermo physical, rheological and electrostatic properties of substances allows you to create nanomaterials based on various scenarios of emergency situations and apply them to reduce the fire risk at oil and gas facilities.

4. The implementation of the technology for controlling the properties of substances should be carried out when developing requirements for designing nanomaterials, assessing fire risks for technologies for creating, operating and using nanofluids and composite materials under conditions of possible emergencies at oil and gas facilities, as well as economic assessment of the prospects for using nanomaterials enterprises.

\section{REFERENCES}

1. Benes, J., Chauvet M., Kamenik, O., Kumhof, M., Laxton, D., Mursula, S., Selody, J. (2015). The future of oil: Geology versus technology. International Journal of Forecasting, vol. 31, no. 1, 207-221. https:// doi.org/10.1016/j.ijforecast.2014.03.012.

2. Mitchell, J. V., Marcel, V., Mitchell, B. (2012) What next for the oil and gas industry? London. Chat-ham House. p.112.

3. Lu, H., Guo, L., Azimi, M., Huang, K. (2019). Oil and Gas 4.0 era: A systematic review and outlook. Computers in Industry, 111, 68-90. https://doi. org/10.1016/j.resconrec.2016.01.010.

4. Nolan, D.P. (2014). Handbook of fire and explosion protection engineering principles: for oil, gas, chemical and related facilities. William Andrew. https://doi. org/10.1016/B978-1-4377-7857-1.00001-X.

5. Morgan, A.B. (2019). The future of flame retardant polymers-unmet needs and likely new approach-es. Polymer Reviews, vol. 59, no. 1, 25-54. https://doi. org/10.1080/15583724.2018. 1454948.

6. Shah, K.A., Tali, B. A. (2016). Synthesis of carbon nanotubes by catalytic chemical vapour deposi-tion: A review on carbon sources, catalysts and substrates. Materials Science in Semiconductor Processing, vol. 41, 67-82. https://doi.org/10.1016/j. mssp.2015.08.013.

7. Ivanov, A.V., Ivakhnyuk, G.K., Medvedeva, L.V. (2016). Methods of control properties of hydrocar-bon liquids in the problems of fire safety. Fire and Explosion Safety, vol. 25, no. 9, 30-37. https:// doi.org/10.18322/PVB.2016.25.09.30-37.

8. Jorio, A., Pimenta, M. A., Souza Filho, A. G., Saito, R., Dresselhaus, G., Dresselhaus, M. S. (2003). Characterizing carbon nanotube samples with resonance Raman scattering. New Journal of Phys-ics, vol. 5, no.1, 139.

9. Von Hippel, A. R. (1954). Dielectrics and waves. Boston, London. Artech House. p. 279.

10. Khaleduzzaman, S. S., Mahbubul, I. M., Shahrul, I. M., Saidur, R. (2013). Effect of particle concen-tration, temperature and surfactant on surface tension of nanofluids. International Communications in Heat and Mass Transfer, vol. 49, 110-114. https://doi. org/10.1016/j.icheatmasstransfer.2013.10.010. 
11. Rugar, D., Hansma, P. (1990). Atomic force microscopy. Physics today, 43(10), 23-30. DOI: 10.1063/1.881238.

12. Hartnett, J.P., Irvine, T.F., Greene G.A., Cho, Y.I. (1998). Advances in heat transfer. Academic press. p. 484.

13. Ivanov, A.V., Sorokin, A.Yu., Ivakhnyuk, G.K., Demekhin, F.V. (2018). Management of electrostatic properties hydrocarbon liquids by modification with carbon nanostructures. Fire and Explosion Safety, vol. 26, no. 7, 16-27. https://doi.org/10.18322/ PVB.2017.26.07.16-27

14. Sharovarnikov A.F., Melnikov A.I. (2015). Experimental studies of fire extinguishing capacity of the water film forming solutions containing fluorinated surfactants. Fire and Explosion Safety, vol. 24, no. 9, 7481. https://doi.org/10.18322/PVB.2015.24.09.74-81.

15. Beheshti, A., Heris, S.Z. (2016). Is MWCNT a good synergistic candidate in APP-PER-MEL intu-mescent coating for steel structure? Progress in Organic Coatings, vol. 90, 252-257. https://doi.org/10.1016/j. porgcoat.2015.10.023.

16. Muradyan, V.E., Sokolov, E.A., Babenko, S.D., Moravsky, A.P. (2010). Microwave dielectric proper-ties of composites modified by carbon nanostructures. Technical Physics, vol. 55, no. 2, 242-246. https:// doi.org/10.1134/S1063784210020131.

17. Liu, X., Spencer, J.S., Kaiser, A.B., Arnold, W.M. (2004). Electric-field oriented carbon nanotubes in different dielectric solvents. Current Applied Physics, vol. 4, no. 2-4, 125-128. https://doi.org/10.1016/j. cap.2003.10.012.

18. Yu, W., Xie, H. (2012). A review on nanofluids: preparation, stability mechanisms, and applications. Journal of Nanomaterials, vol. 2012, 17. https://doi. org/10.1155/2012/435873.

19. Bikiaris, D. (2011). Can nanoparticles really enhance thermal stability of polymers? Part II: an over-view on thermal decomposition of polycondensation polymers. Thermochimica Acta, vol. 523, no. 1-2, 25-45. https://doi.org/10.1016/j.tca.2011.06.012.

20. Mukherjee, S., Paria, S. (2013). Preparation and stability of nanofluids-a review. IOSR Journal of Mechanical and civil engineering, vol. 9, no. 2, 63-69. https://doi.org/10.9790/1684-0926369.
21. Lumsdon, S.O., Scott, D.M. (2005). Assembly of colloidal particles into microwires using an alternating electric field //Langmuir, vol. 21, no. 11, 4874-4880. https://doi.org/10.1021/la0472697.

22. Ivanov, A.V., Ivakhnyuk, G.K., Emelyanova, A.N. (2015). Flash test of kerosene with dispersed carbon nanotubes andvariable frequency-modulated electric potential. Problems of Technosphere Risk Management, no. 2(27), 53-57.

23. Ivanov, A.V., Miftakhutdinova, A.A., Nefedyev, S.A., Simonova, M. A., Maslakov, M.D. (2017). Conditions for the stabilization nanostructures for the fireproof transport flammable liquids. Fire and Explosion Safety, vol. 26, no. 9, 35-43. https://doi.org/10.18322/ PVB.2017.26.09.35-43.

24. Ivanov, A.V., Toropov, D.P., Ivakhnyuk, G.K., Fedorov, A.V., Kuzmin, A.A. (2017). Research of the extinguishing properties of water and hydrogel with carbon nanoparticles for liquidation burning of the petroleum products. Fire and Explosion Safety, vol. 26, no. 8, 31-44. https://doi.org/ 10.18322/ PVB.2017.26.08.31-44.

25. Toropov, D., Ivanov, A., Dali, F., Perlin, A., Lebedev, A., Shidljvsky, G. (2019). Extinguishing characteristics of water suspensions with carbon nanostructures at extinguishing liquid hydrocarbons fires (oil and gas industry). Delta, 13(1), 22-31. https://doi. org/10.17423/delta.2019.13.1.55.

26. Ivanov, A.V., Mikhaylova, V.I., Ivakhnyuk, G.K., Demekhin, F.V. Investigation of the characteristics of modified hydrogels for thermal protection of petroleum products tanks. Fire and Explosion Safety, 2017, vol. 26, no. 4, 58-67. https://doi.org/10.18322/ PVB.2017.26.04.58-67.

27. Ivanov, A.V., Miftakhutdinova, A.A., Ivakhnyuk, G. K., Basharichev, A.V. (2018). Physical and tech-nological principles and methodology for the management of fire protection processes when treating liquid hydrocarbon in the conditions of stabilization of nanostructures. Fire and Explosion Safety, vol. 27, no. 12, 7-18. https://doi.org/10.18322/PVB.2018.27.12.718.

Paper submitted: 17.05.2020.

Paper accepted: 29.10.2020.

This is an open access article distributed under the CC BY 4.0 terms and conditions. 